\title{
Article
}

\section{Variation in Growth, Physiology, Yield, and Quality of Wheat under the Application of Different Zinc Coated Formulations}

\author{
Qudsia Nazir ${ }^{1,2}$, Xiukang Wang ${ }^{3, *}$, Azhar Hussain ${ }^{4, *}$, Allah Ditta ${ }^{5,6}{ }^{\circ}$, Ayesha Aimen ${ }^{4}$, Ifra Saleem ${ }^{1,2}$, \\ Muhammad Naveed ${ }^{2}$, Tariq Aziz ${ }^{2}$, Adnan Mustafa ${ }^{7}$ and Nalun Panpluem ${ }^{8}$ \\ 1 Soil Chemistry Section, Ayub Agricultural Research Institute, Faisalabad 38000, Pakistan; \\ sbqnazir@gmail.com (Q.N.); ifrasaleem@gmail.com (I.S.) \\ 2 Institute of Soil and Environmental, University of Agriculture, Faisalabad 38000, Pakistan; \\ mnaveeduaf@gmail.com (M.N.); draziz@uaf.edu.pk (T.A.) \\ 3 College of Life Sciences, Yan'an University, Yan'an 716000, China \\ 4 Department of Soil Science, The Islamia University of Bahawalpur, Punjab 63100, Pakistan; \\ ayeshaaimen500@gmail.com \\ 5 Department of Environmental Sciences, Shaheed Benazir Bhutto University Sheringal, Upper Dir, \\ Khyber Pakhtunkhwa 18000, Pakistan; allah.ditta@sbbu.edu.pk \\ 6 School of Biological Sciences, The University of Western Australia, 35 Stirling Highway, \\ Perth, WA 6009, Australia \\ 7 Biology Center CAS, SoWa RI, Na Sadkach 7, 370-05 České Budějovice, Czech Republic; \\ adnanmustafa780@gmail.com \\ Citation: Nazir, Q.; Wang, X.; \\ 8 School of Agriculture Cooperative and Agricultural Economics, Sukhothai Thamathirat Open University, \\ Bangkok 11120, Thailand; pp.pilun@gmail.com \\ * Correspondence: wangxiukang@yau.edu.cn (X.W.); azharhaseen@gmail.com (A.H.)
} Hussain, A.; Ditta, A.; Aimen, A.; Saleem, I.; Naveed, M.; Aziz, T.; Mustafa, A.; Panpluem, N. Variation in Growth, Physiology, Yield, and Quality of Wheat under the Application of Different Zinc Coated Formulations. Appl. Sci. 2021, 11, 4797. https://doi.org/10.3390/ app11114797

Academic Editor: Dionisios Gasparatos

Received: 17 April 2021

Accepted: 19 May 2021

Published: 24 May 2021

Publisher's Note: MDPI stays neutral with regard to jurisdictional claims in published maps and institutional affiliations.

Copyright: (c) 2021 by the authors Licensee MDPI, Basel, Switzerland. This article is an open access article distributed under the terms and conditions of the Creative Commons Attribution (CC BY) license (https:/ / creativecommons.org/licenses/by/ $4.0 /)$.

Abstract: Zinc ( $\mathrm{Zn})$ is critical for the activity of many enzymes including involved photosynthetic $\mathrm{CO}_{2}$ fixation and indirectly involved in the production of growth hormones and internode elongation in crop plants. In this regard, a field experiment was conducted to investigate the comparative effectiveness of the $\mathrm{Zn}$ blended, $\mathrm{Zn}$ coated and bio-activated $\mathrm{Zn}$ coated urea on the growth, physiological, yield, and quality of wheat. Three types of urea were prepared including bio-activated Zn coated, Zn coated and Zn blended urea. The bio-activated Zn coated urea was prepared by inoculating the powdered organic material with Zn solubilizing bacterium (Bacillus sp. AZ6) and then this material was mixed with $\mathrm{ZnO}$. This bioactive $\mathrm{Zn}$ was coated on urea at the rate to formulate $1.5 \%$ bio-activated $\mathrm{Zn}$ coated urea. Moreover, Zn blended urea was prepared by mixing powder $\mathrm{ZnO}$ with urea while $\mathrm{Zn}$ coated urea with $1.5 \% \mathrm{Zn}$ was prepared by mixing $\mathrm{ZnO}$ and urea under proper moisture conditions to ensure proper coating. In results, growth parameters were significantly increased with the application of bio-activated $\mathrm{Zn}$ coated urea as compared to other urea formulations and the control. The same treatment caused the maximum increase in quality parameters like oil contents $(55 \%)$, protein $(30 \%)$, and $\mathrm{N}$ concentration $(30 \%)$ as compared to the control. In conclusion, the application of $1.5 \%$ bio-activated $\mathrm{Zn}$ coated urea was highly effective in enhancing the growth, physiological, yield, and quality parameters of wheat.

Keywords: zinc; Zn biofortification; zinc solubilizing bacteria; bioactivated zinc; urea

\section{Introduction}

Zn plays a critical role in various physiological processes (maintains the structural integrity of rubisco, influx rate of $\mathrm{K}^{+}$in cells, and opening of stomata) of crop plants [1-3]. In plants, Zn affects water uptake and its transport [4] and reduces the adverse effects of heat [5] and salinity stress [6] by inducing the production of $\mathrm{H}_{2} \mathrm{O}_{2}$-scavenging glutathione reductase and ascorbate peroxidase [7]. $\mathrm{Zn}$ is required for the synthesis of tryptophan, which is a precursor of indole acetic acid, protein, and nucleic acid synthesis, energy production, carbohydrate and lipid metabolisms [1,3]. 
Wheat is the most vital cereal and staple crop cultivated in Pakistan [8]. It contributes about $1.7 \%$ to gross domestic product (GDP). During 2019-2020, wheat was grown on an area of $8825^{\prime} 000^{\prime}$ ha with $24,946^{\prime} 000^{\prime}$ tones production [9]. In the cereal-based cropping system, Zn deficiency is a widespread chronic problem among the human population and is expected to increase up to 138 million by 2050. More than 0.1 million deaths, especially in young children, are expected due to diarrhea and pneumonia caused by Zn deficiency [10].

Being an essential micronutrient, Zn plays an important role in improving the growth, physiological, yield, and quality parameters of various crops. However, Zn deficient soils are widespread in subtropical regions of the world and the main reason behind this deficiency is the cereal-based cropping system prevailing in these regions. Moreover, plants grown on such soils show Zn deficiency, and overall plant growth, physiology, and quality are disturbed. Pakistani soils are $\mathrm{Zn}$ deficient due to more $\mathrm{CaCO}_{3}$ contents with high soil $\mathrm{pH}$ and less organic matter [11-13]. Due to Zn deficiency, the crops, especially cereal crops, cultivated on such soils have low Zn contents in grains. Therefore, it is a need of the hour to find out some sustainable and cost-effective approaches to combat $\mathrm{Zn}$ deficiency in soils and ultimately in food grains.

Among various strategies, biofortification through the soil and/or foliar application of Zn through chemical fertilizers, seed coating, impregnated fertilizers, etc., are mainly practiced [14]. Zinc application in soil not only increases the growth and yield of plants but also improves overall vigor and quality parameters such as sugars and oil contents [15]. However, due to the high cost involved and environmental degradation caused, it is not an eco-friendly strategy. Moreover, coating of natural materials on different fertilizers has also been the interest of scientists in recent studies aimed at improving the fertilizer use efficiency and subsequent improvement of crop yields [16,17].

Fertilizer management is a technique aimed to improve plant vigor, quality, and plant physiology under various cropping systems [18,19]. The most commonly used source of $\mathrm{Zn}$ in Pakistan is $\mathrm{ZnSO}_{4}$, but due to its high cost and scarcity or even unavailability in the market, farmers are reluctant to use it. $\mathrm{ZnO}$ is an effective source as it contains $80 \%$ $\mathrm{Zn}$ contents but in an insoluble form. This insoluble Zn can be solubilizing by ZSB (zinc solubilizing bacteria). Zn solubilizing bacteria are capable of enhancing Zn bioavailability in the soil through the secretion of organic acids, chelating agents, and siderophores [20-24]. Moreover, other plant growth promotion activities possessed include the solubilization of nutrients such as phosphorus, alleviation of ethylene stress through ACC-deaminase activity, and production of phytohormones to enhance root growth for efficient uptake of nutrients, acting as biocontrol agents, etc. [25-27]. By keeping the above-mentioned facts in mind, a field experiment was conducted in which the impact of different $\mathrm{Zn}$ formulations, i.e., $\mathrm{ZnO}$ coated, blended and bio-activated $\mathrm{Zn}$ coated urea, were investigated on the growth, yield, quality, and physiological parameters of wheat.

\section{Materials and Methods}

A field experiment was conducted in the farm area of the Institute of Soil and Environmental Sciences, University of Agriculture, Faisalabad, Pakistan using wheat as a test crop. The comparative effectiveness of $\mathrm{Zn}$ blended, $\mathrm{Zn}$ coated, and bio-activated $\mathrm{Zn}$ coated urea was evaluated for physiological, quality, and biochemical parameters under field conditions for the wheat crop (FSD-2008). The weather data regarding average temperature $\left({ }^{\circ} \mathrm{C}\right)$ and rainfall $(\mathrm{mm})$ during the cropping season from October 2014 to April 2015 is presented in Figure 1.

\subsection{Soil Analysis}

Composite soil samples were taken randomly from the experimental field, air-dried, ground, sieved $(2 \mathrm{~mm})$, and analyzed regarding carious physicochemical characteristics following standard procedures [28-32]. The soil sandy clay loam in texture (sand 52.3\%; silt $28.5 \%$; clay $19.2 \%$ ) with $\mathrm{pH}=7.85$, electrical conductivity $(\mathrm{EC})=1.43 \mathrm{dS} \mathrm{m}^{-1}$, organic 
matter $=0.69 \%$, total nitrogen $=0.07 \%$, available phosphorus $=8.6 \mathrm{mg} \mathrm{kg}^{-1}$; extractable potassium $=85 \mathrm{mg} \mathrm{kg}^{-1}$; and plant available $\mathrm{Zn}=0.66 \mathrm{mg} \mathrm{kg}^{-1}$.

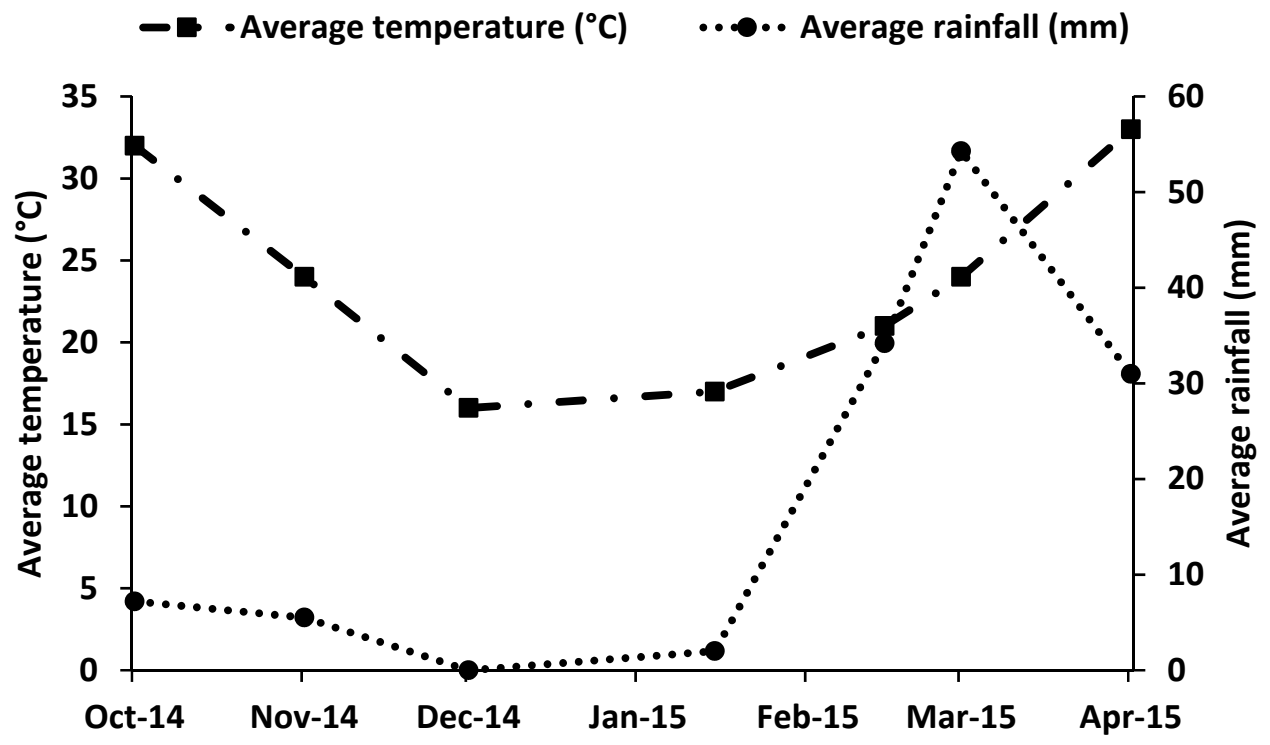

Figure 1. Average temperature $\left({ }^{\circ} \mathrm{C}\right)$ and rainfall $(\mathrm{mm})$ during the cropping season from October 2014 to April 2015.

\subsection{Preparation of Different Urea Formulations}

Earlier, we isolated zinc-solubilizing bacteria from the maize rhizosphere by using the dilution plate technique on nutrient agar medium [33]. The inoculum of the strain AZ6 was prepared by growing it in a $1000 \mathrm{~mL}$ conical flask containing Bunt and Rivera basal medium [34]. The inoculated flasks were incubated $\left(28 \pm 1^{\circ} \mathrm{C}\right)$ for $72 \mathrm{~h}$ in the orbital shaking incubator at $100 \mathrm{rpm}$. Before using inoculum, an optical density of 0.5 at $535 \mathrm{~nm}$ was maintained with $10^{8}-10^{9}$ colony-forming units (CFU) $\mathrm{mL}^{-1}$. This suspension (inoculum) of the bacterial strain was used for urea coating to prepare bio-activated $\mathrm{Zn}$ coated urea [20]. Briefly, powdered organic material (plant residues) was first dried in an oven at $80^{\circ} \mathrm{C}$, inoculated with bacterial strain AZ6, and incubated for $72 \mathrm{~h}$ at $30 \pm 1{ }^{\circ} \mathrm{C}$ in an incubator. Then, this bio-augmented organic material was thoroughly mixed with 300-400 mesh size $\mathrm{ZnO}$ in the ratio of 40:60 w/w (powder $\mathrm{ZnO}$ : bio-augmented organic material). This mixture was again incubated for 3 days at $30 \pm 1{ }^{\circ} \mathrm{C}$ to achieve maximum chelation of $\mathrm{Zn}$ with organic complexes. The bio-activated $\mathrm{Zn}$ was coated on urea at $1.5 \%$ $(w / w)$ to prepare bio-activated $\mathrm{Zn}$ coated urea. Before impregnation/coating on urea granules, the bio-activated Zn complex was once again passed through 300-400 mesh size sieves. All the precautions were used and there was no change in the composition of urea. To prepare Zn coated urea, bacterial strain AZ6 was not used and Zn $(1.5 \% w / w)$ was coated using $\mathrm{ZnO}$ with proper moisture contents while $\mathrm{Zn}$ blended urea was prepared by mixing a certain amount of $\mathrm{ZnO}$ at $1.5 \% \mathrm{Zn}(w / w)$ [35].

\subsection{Experimental Description}

The field experiment was conducted with six treatments including $\mathrm{T}_{0}=$ control (no $\mathrm{Zn}$ ), $\mathrm{T}_{1}=\mathrm{ZnSO}_{4}$ (recommended), $\mathrm{T}_{2}=\mathrm{ZSB}$ (zinc solubilizing bacteria), $\mathrm{T}_{3}=1.5 \% \mathrm{Zn}$ coated urea, $\mathrm{T}_{4}=1.5 \%$ bio-activated $\mathrm{Zn}$ coated urea, $\mathrm{T}_{5}=1.5 \% \mathrm{Zn}$ blended urea. The treatments were arranged following randomized complete block design (RCBD) in triplicate. Seeds of wheat variety FSD-2008 were purchased from Ayub Agriculture Research Institute, Faisalabad, and sown in the field using a hand drill. Each experimental unit had an area of $35 \mathrm{~m}^{2}$. Chemical fertilizers such as urea, di-ammonium phosphate, and sulfate of potash were used as NPK sources at 160:110:90 $\mathrm{kg} \mathrm{ha}^{-1}$. Zinc was applied at the rate of $5 \mathrm{~kg} \mathrm{ha}^{-1}$. Recommended agronomic practices such as weeding, hoeing, etc. were 
performed. The crop was harvested at maturity and data regarding growth, yield, and biochemical parameters were taken.

\subsection{Growth and Yield Parameters}

The plant height and spike length were measured with the help of a measuring tape from top to bottom. No. of tillers plant ${ }^{-1}$ were counted manually. At maturity, the yield parameters such as 100-grain weight, grain yield, and biomass production per hectare of wheat were recorded.

\subsection{Physiological Parameters}

\subsubsection{Electrolyte Leakage}

Electrolyte leakage was determined by the method described by [36]. Leaf samples were washed with double deionized water (DDW) to remove any surface contamination, cut into leaf discs, put into the closed vial containing DDW $(10 \mathrm{~mL})$, incubated on a rotatory shaker for $24 \mathrm{~h}$, and electrical conductivity of the solution $\left(E C_{1}\right)$ was determined by using an electrical conductivity meter (Jenway 4070, ELE, England, UK). Then, vials with leaf samples were autoclaved at $120^{\circ} \mathrm{C}$ for $20 \mathrm{~min}$., cooled, and electrical conductivity $\left(E C_{2}\right)$ was again measured. The following formula was used to calculate electrolyte leakage:

$$
\text { Electrolyte leakage }(\%)=\frac{E C_{1}}{E C_{2}} \times 100
$$

\subsubsection{Carbonic Anhydrase Activity}

Carbonic anhydrase (CA) activity was determined by following the method proposed by [37]. Briefly, leaf samples were cut into small pieces $\left(1 \mathrm{~cm}^{2}\right)$, mixed, and $200 \mathrm{mg}$ leaf pieces were weighed and suspended in $0.2 \mathrm{M}$ cysteine hydrochloride solution. The samples were incubated at $40{ }^{\circ} \mathrm{C}$ for $20 \mathrm{~min}$., blotted, and transferred to the test tubes containing phosphate buffer ( $\mathrm{pH} 6.8$ ), followed by the addition of $0.2 \mathrm{M}$ alkaline bicarbonate solution and $0.002 \%$ bromothymol blue indicator, and incubated at $50{ }^{\circ} \mathrm{C}$ for $20 \mathrm{~min}$. After the addition of $0.2 \mathrm{~mL}$ of methyl red indicator, the reaction mixture was titrated against $0.05 \mathrm{~N}$ $\mathrm{HCl}$. The $\mathrm{CA}$ activity was calculated and expressed as $\mu \mathrm{mol} \mathrm{CO} \mathrm{kg}^{-1} \mathrm{FW} \mathrm{s}^{-1}$.

\subsection{Quality Parameters}

\subsubsection{Oil Contents}

The oil contents in each flour sample were determined using the Soxhlet apparatus [38]. Briefly, five grams of flour was extracted with petroleum ether and condensed at the rate of 2-3 drops s ${ }^{-1}$ for $8 \mathrm{~h}$. After distillation of excess ether, the residue remaining in the extraction flask was dried at $100{ }^{\circ} \mathrm{C}$ for half an hour until a constant weight was achieved. Oil contents were calculated by using the following formula:

$$
\text { Oil contents }(\%)=\frac{\text { Weight of ether extract }}{\text { Weight of flour sample }} \times 100
$$

\subsubsection{Ash Contents (Mineral Contents)}

The ash contents in each grain sample were determined by following the procedure mentioned in AACC [38]. The whole grain sample taken in pre-weighed crucibles were on Bunson burner before incinerating in the muffle furnace where a temperature of $550{ }^{\circ} \mathrm{C}$ was maintained until the sample converted to gray whitish residue.

$$
\text { Ash contents }(\%)=\frac{\text { Weight of residue }}{\text { Weight of sample }} \times 100
$$




\subsubsection{Nitrogen and Crude Protein in Grain Samples}

Nitrogen contents in wheat grains samples were determined by Kjeldahl method [39]. The crude protein concentration was calculated by multiplying nitrogen concentration in grain samples with a conversion factor of 5.7 [40].

\subsubsection{Zinc Contents in Grain Samples}

Air-dried and ground, grain sample ( $1 \mathrm{~g})$ was placed in the digestion flask and tri-acid $\left(\mathrm{HNO}_{3}, \mathrm{H}_{2} \mathrm{SO}_{4}, \mathrm{HClO}_{4}\right)$ reagent $(10 \mathrm{~mL})$ was added and held overnight. The samples were heated on the hot plate carefully the next day until the production of red $\mathrm{NO}_{2}$ fumes was ceased. The flasks were allowed to cool down and then $2-4 \mathrm{~mL} \mathrm{HClO}_{4}(70 \%)$ was added. The samples were heated again to reduce volume via evaporation. When the vapors were condensed, contents of the flask were transferred to a volumetric flask $(50 \mathrm{~mL})$ and volume was made up to the mark with DDW. For control, the same procedure was performed except it was without a grain sample. Samples were then filtered and used for $\mathrm{Zn}$ determination via atomic absorption spectrophotometer (PerkinElmer, Analyst 100, Waltham, MA, USA). A calibration curve was prepared by using working standards prepared from the stock solution. The stock solution was made by dissolving $\mathrm{ZnSO}_{4} \cdot 7 \mathrm{H}_{2} \mathrm{O}$ $\left(4.398 \mathrm{~g} \mathrm{~L}^{-1}\right)$. The sub-stock solution of $100 \mathrm{ppm}$ was prepared by taking $10 \mathrm{~mL}$ stock solution in a $100 \mathrm{~mL}$ flask. The volume was made with DDW. The working standards of $0.5,1,1.5,2,2.5$, and $3 \mathrm{mg} \mathrm{L}^{-1}$ were prepared by taking sub-stock solution.

\subsubsection{Statistical Analysis}

A computer-based software i.e., Statistix v. 8.1 (Analytical Software, Tallahassee, FL, USA) was used to calculate analysis of variance for the collected data and treatment means were compared by least significant difference (LSD) test at $\alpha=0.05$ [41].

\section{Results}

\subsection{Growth Parameter}

All treatments i.e., $\mathrm{Zn}$ coated, $\mathrm{Zn}$ blended, and bio-activated $\mathrm{Zn}$ coated urea showed a statistically significant $(p<0.05)$ effect on growth parameters but the maximum increase was recorded in the treatment where $1.5 \%$ bio-activated $\mathrm{Zn}$ coated urea was applied. Figure 2a shows a significant effect of $\mathrm{Zn}$ coated urea on plant height as compared to the control treatment where no $\mathrm{Zn}$ was applied. With the application of $1.5 \%$ bio-activated $\mathrm{Zn}$ coated urea $(87.5 \mathrm{~cm})$, an increase of 25.33 and $2.6 \%$ was recorded in plant height as compared to the control $(65.3 \mathrm{~cm})$ and recommended $\mathrm{Zn}$ as $\mathrm{ZnSO}_{4}(85.16 \mathrm{~cm})$ treatments, respectively. With the application of recommended $\mathrm{Zn}, 1.5 \% \mathrm{Zn}$ coated $(86.8 \mathrm{~cm})$ and $1.5 \% \mathrm{Zn}$ blended urea $(80.7 \mathrm{~cm})$, an increase of $23.28,24.76$, and $19.01 \%$, respectively, were observed compared to the control. While the treatment where only $\mathrm{Zn}$ solubilizing bacteria (ZSB) were used $(66.5 \mathrm{~cm}), 1.75 \%$ increase compared to the control was observed. The application of $1.5 \%$ bio-activated $\mathrm{Zn}$ coated urea caused an increase of 0.8 and $8.5 \%$ in plant height as compared to $1.5 \% \mathrm{Zn}$ coated and $1.5 \% \mathrm{Zn}$ blended urea, respectively.

Bio-activation and coating of $\mathrm{Zn}$ on urea showed a significant effect $(p<0.05)$ on spike length of wheat as shown in Figure 2b. The data clearly showed that the application of $1.5 \%$ bio-activated $\mathrm{Zn}$ coated urea $(11.25 \mathrm{~cm})$ caused the maximum increase $(33.95 \%)$ compared to the control $(7.43 \mathrm{~cm})$. The application of ZSB $(8.50 \mathrm{~cm})$ showed an almost $29 \%$ increase over the control. The application of $1.5 \% \mathrm{Zn}$ coated $(10.50 \mathrm{~cm})$ and $1.5 \% \mathrm{Zn}$ blended urea $(9.50 \mathrm{~cm}$ ) showed 29.23 and $33 \%$ increase, respectively. On the other hand, $27.51 \%$ increase in spike length was recorded with the application of recommended $\mathrm{Zn}$ $(10.25 \mathrm{~cm})$ as compared to the control. The application of $1.5 \%$ bio-activated $\mathrm{Zn}$ coated urea showed $8.8 \%$ increase in spike length as compared to recommended $\mathrm{Zn}$ as $\mathrm{ZnSO}_{4}$. The application of $1.5 \%$ bio-activated $Z n$ coated urea caused an increase of 7.1 and $18.4 \%$ in spike length as compared to $1.5 \% \mathrm{Zn}$ coated and $1.5 \% \mathrm{Zn}$ blended urea, respectively. 


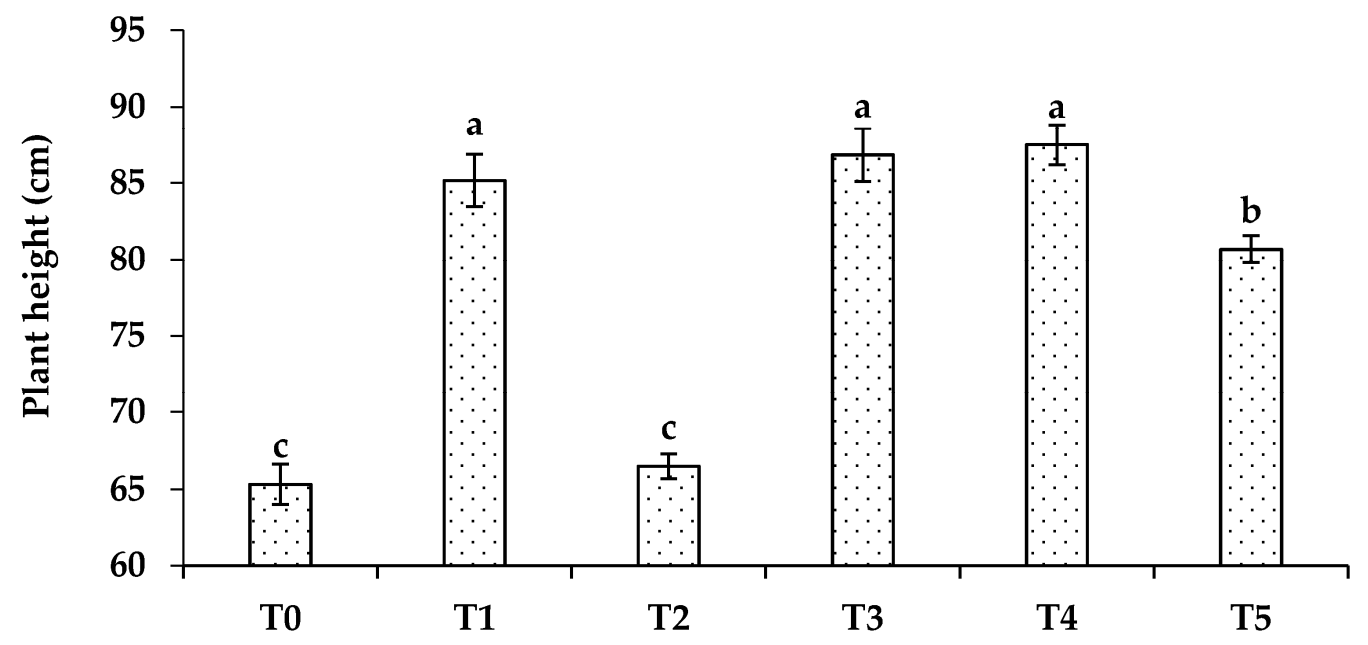

(a)

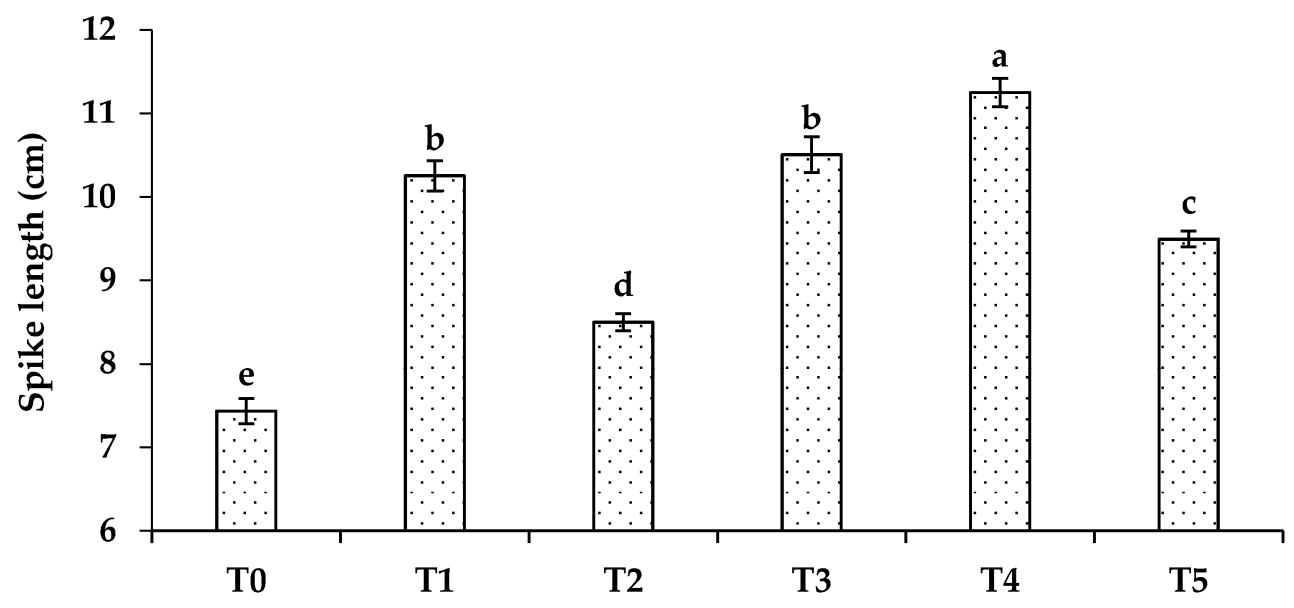

(b)

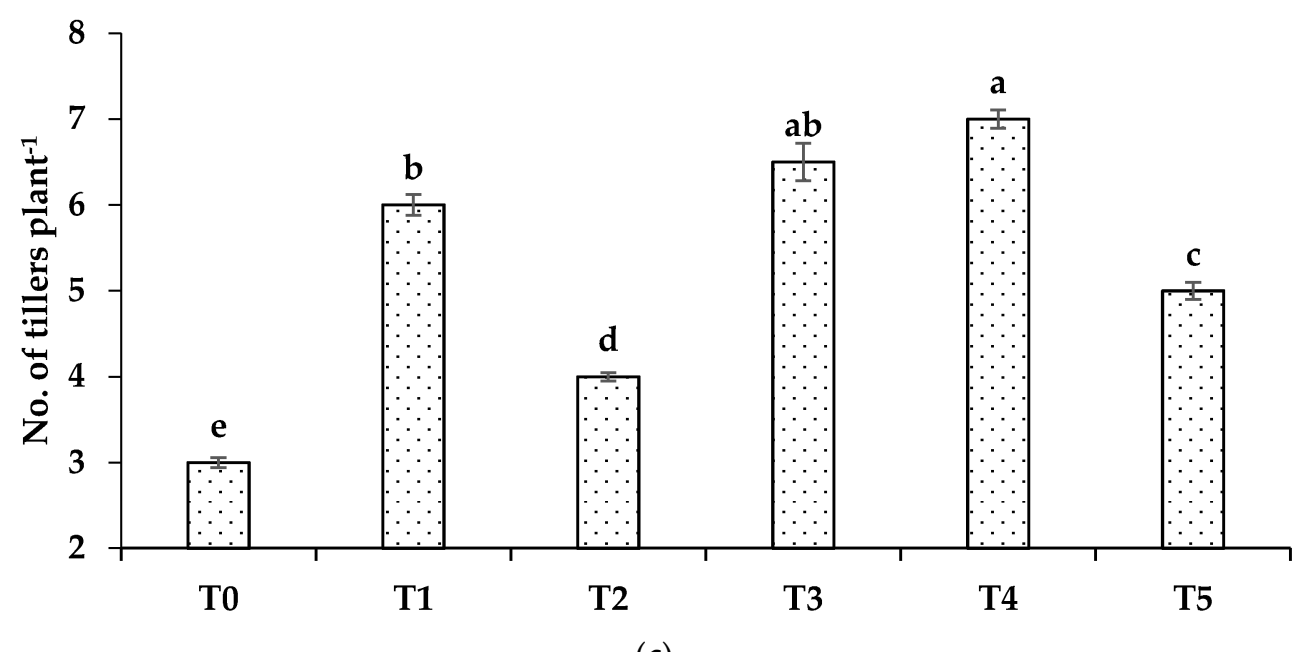

(c)

Figure 2. Growth parameters of wheat: (a) plant height; (b) spike length; (c) No. of tillers per plant, grown with different formulations of urea. Where $\mathrm{T}_{0}=\mathrm{No} \mathrm{Zn} ; \mathrm{T}_{1}=$ recommended $\mathrm{Zn}\left(\mathrm{ZnSO}_{4}\right) ; \mathrm{T}_{2}=\mathrm{ZSB} ; \mathrm{T}_{3}=1.5 \% \mathrm{Zn}$ coated urea $(\mathrm{ZnO}) ; \mathrm{T}_{4}=$ $1.5 \%$ bio-activated $\mathrm{Zn}$ coated urea $(\mathrm{ZnO})$; and $\mathrm{T}_{5}=1.5 \% \mathrm{Zn}$ blended urea $(\mathrm{ZnO})$. Bars showing the same letters do not differ significantly $(p<0.05)$. 
The impact of $\mathrm{Zn}$ application on the no. of tillers plant ${ }^{-1}$ is presented in Figure 2c. The data indicated that all treatments showed a statistically significant effect $(p<0.05)$ on the no. of tillers plant ${ }^{-1}$ as compared to the control (no $\mathrm{Zn}$ ). For example, alone application of ZSB (4) showed $25 \%$ increase in no. of tillers plant ${ }^{-1}$ as compared to the control while the maximum increase $(57.14 \%)$ was recorded with the application of $1.5 \%$ bio-activated $\mathrm{Zn}$ coated urea (7), followed by ZSB (42.85\%), $1.5 \%$ Zn blended urea $(28.57 \%)$, recommended $\mathrm{Zn}(14.28 \%)$ and $1.5 \% \mathrm{Zn}$ coated urea (7.14\%) compared to the control. The application of $1.5 \%$ bio-activated $\mathrm{Zn}$ coated urea caused an increase of 7.7 and $40.0 \%$ in no. of tillers plant $^{-1}$ as compared to $1.5 \% \mathrm{Zn}$ coated and $1.5 \% \mathrm{Zn}$ blended urea, respectively.

\subsection{Physiological Parameters}

Regarding the effect of $\mathrm{Zn}$ application in the form of $\mathrm{Zn}$ coated, $\mathrm{Zn}$ blended, bioactivated Zn coated urea, and ZSB (Bacillus sp.), a statistically significant $(p<0.05)$ effect on electrolyte leakage of wheat was observed in Figure 3a.

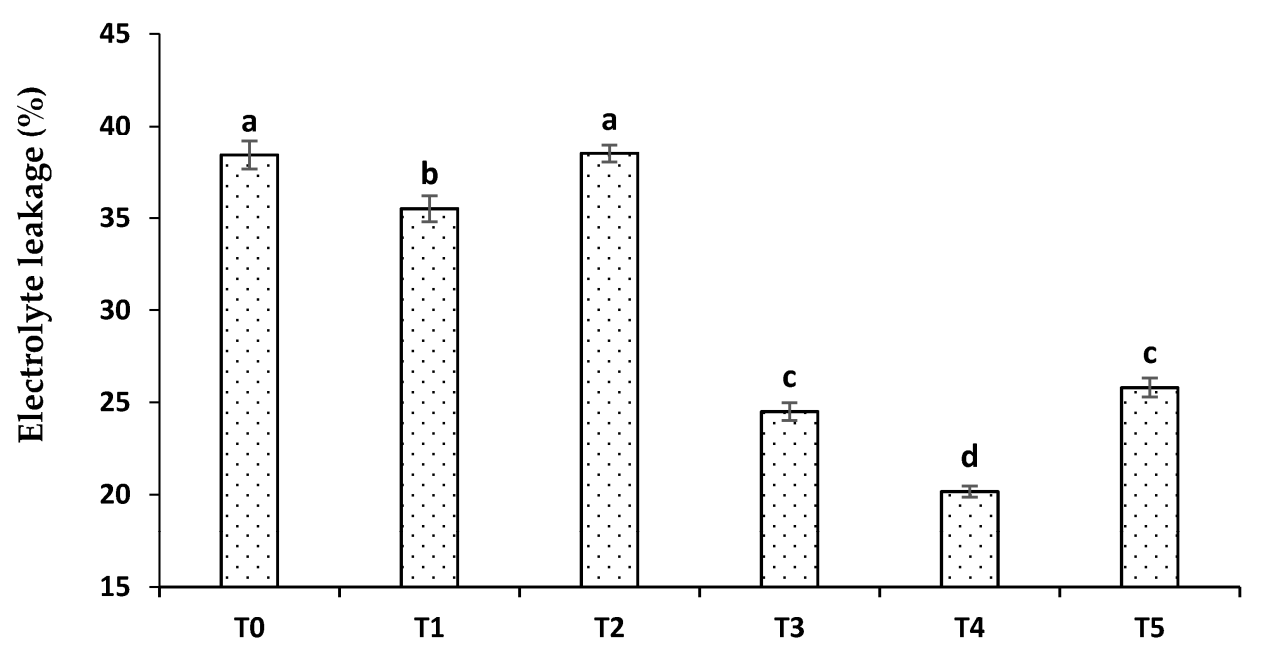

(a)

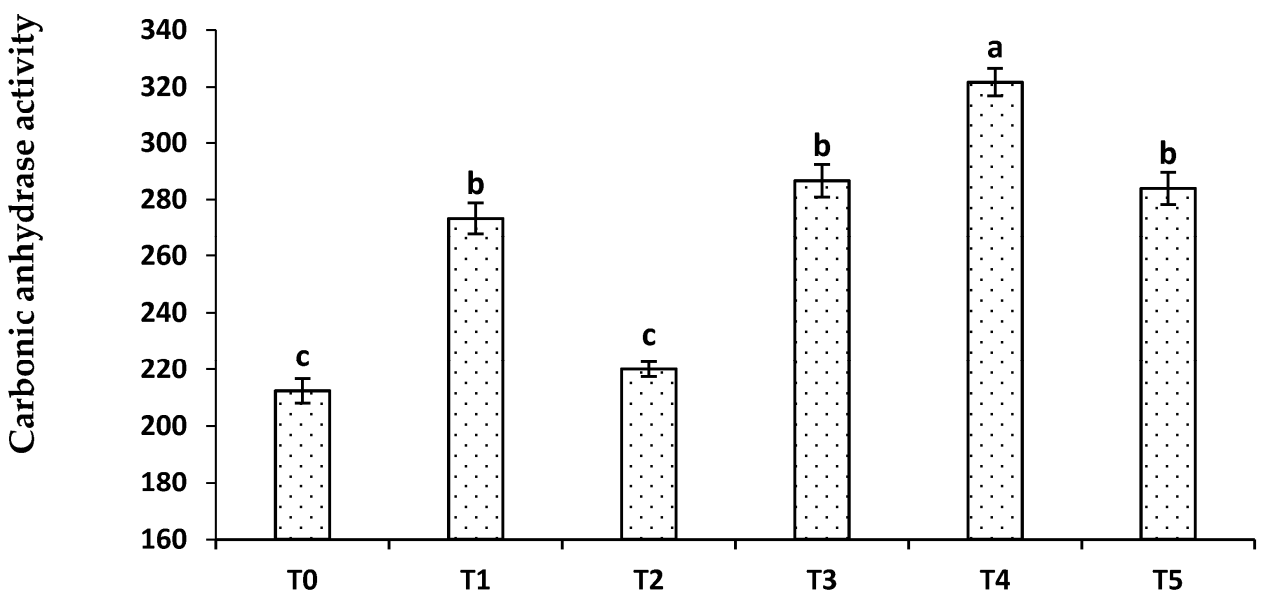

(b)

Figure 3. Comparative effectiveness of different $\mathrm{Zn}$ formulations of urea regarding electrolyte leakage and carbonic anhydrase activity of wheat: $(\mathbf{a})=$ Electrolyte leakage $(\%)$ and $(\mathbf{b})=$ carbonic anhydrase activity. Treatments are as, $\mathrm{T}_{0}=\mathrm{No}$ $\mathrm{Zn} ; \mathrm{T}_{1}=$ recommended $\mathrm{Zn}\left(\mathrm{ZnSO}_{4}\right) ; \mathrm{T}_{2}=\mathrm{ZSB} ; \mathrm{T}_{3}=1.5 \% \mathrm{Zn}$ coated urea $(\mathrm{ZnO}) ; \mathrm{T}_{4}=1.5 \%$ bio-activated $\mathrm{Zn}$ coated urea $(\mathrm{ZnO})$; and $\mathrm{T}_{5}=1.5 \% \mathrm{Zn}$ blended urea $(\mathrm{ZnO})$. Means sharing the same letters do not differ significantly $(p<0.05)$.

The maximum electrolyte leakage was observed in the ZSB (38.5\%) and the control where no $\mathrm{Zn}$ was applied (38.4\%) and that of the minimum value $(20.2 \%)$ was recorded with the application of $1.5 \%$ bio-activated $\mathrm{Zn}$ coated urea, which was $40 \%$ less as compared 
to the control treatment. Similarly, 1.5\% Zn blended urea (25.8\%) caused a decrease of $8.7 \%$ in electrolyte leakage as compared to the control. The application of $1.5 \%$ bio-activated $\mathrm{Zn}$ coated urea caused a decrease of 17.7 and $21.8 \%$ in electrolyte leakage as compared to $1.5 \%$ $\mathrm{Zn}$ coated and $1.5 \% \mathrm{Zn}$ blended urea, respectively.

In the case of carbonic anhydrase (CA) activity, the maximum $(321.67 \mu \mathrm{mol} \mathrm{CO}$ $\mathrm{kg}^{-1} \mathrm{~s}^{-1}$ ) was observed in the treatment where $1.5 \%$ bio-activated $\mathrm{Zn}$ coated urea was applied and it was $34 \%$ more as compared to the control $\left(212.33 \mu \mathrm{mol} \mathrm{CO} \mathrm{Kg}^{-1} \mathrm{~s}^{-1}\right)$ Figure 3b. The application of ZSB resulted in $220 \mu \mathrm{mol} \mathrm{CO} \mathrm{kg}^{-1} \mathrm{~s}^{-1} \mathrm{CA}$ activity, which was $4.3 \%$ more as compared to the control. The treatments where $1.5 \% \mathrm{Zn}$ coated and $1.5 \%$ $\mathrm{Zn}$ blended urea was applied showed 286.67 and $284.0 \mu \mathrm{mol} \mathrm{CO} \mathrm{kg}^{-1} \mathrm{~s}^{-1} \mathrm{CA}$ activities, respectively. Recommended $\mathrm{Zn}$ as $\mathrm{ZnSO}_{4}\left(273.33 \mu \mathrm{mol} \mathrm{CO} \mathrm{Cg}^{-1} \mathrm{~s}^{-1}\right)$ showed an almost $21 \%$ increase in CA activity compared to the control. The application of $1.5 \%$ bio-activated Zn coated urea caused an increase of 12.2 and $13.3 \%$ in CA activities as compared to $1.5 \%$ $\mathrm{Zn}$ coated and $1.5 \% \mathrm{Zn}$ blended urea, respectively.

\subsection{Yield Parameters}

A statistically significant effect $(p<0.05)$ of different $\mathrm{Zn}$ formulations on yield parameters of wheat under field conditions compared to the control was observed (Figure 3). The plots treated with $1.5 \%$ bio-activated $\mathrm{Zn}$ coated urea showed 15.75 tons ha ${ }^{-1}$ biomass, which was $4 \%$ more as compared to the control (13.47 tons ha ${ }^{-1}$ biomass), Figure $4 \mathrm{a}$. The treatments with $1.5 \% \mathrm{Zn}$ coated and $1.5 \% \mathrm{Zn}$ blended urea showed 14.83 and 15.13 tons ha ${ }^{-1}$ biomass, respectively and both were about $2 \%$ more as compared to the control. In comparison to the recommended $\mathrm{ZnSO}_{4}$ (14.5 tons ha ${ }^{-1}$ biomass), the application of $1.5 \%$ bio-activated $\mathrm{Zn}$ coated urea caused about $0.6 \%$ increase in biomass. A similar trend was recorded regarding the grain yield of wheat, Figure $4 \mathrm{~b}$. The application of $1.5 \%$ bioactivated $\mathrm{Zn}$ coated urea caused an increase of 6.2 and $4.1 \%$ in biomass as compared to $1.5 \% \mathrm{Zn}$ coated and $1.5 \% \mathrm{Zn}$ blended urea, respectively.

The data regarding grain yield (tons $\mathrm{ha}^{-1}$ ) of wheat showed that a statistically significant increase with the application of different $\mathrm{Zn}$ formulations, Figure $4 \mathrm{~b}$. The application of $1.5 \%$ bio-activated $\mathrm{Zn}$ coated urea yielded 5.60 tons ha ${ }^{-1}$ grains and this was $33 \%$ increase as compared to the control (3.42 tons ha ${ }^{-1}$ grains). Almost similar results were obtained with the application of $1.5 \% \mathrm{Zn}$ coated and $1.5 \%$ bio-activated $\mathrm{Zn}$ coated urea applied. With the application of $1.5 \% \mathrm{Zn}$ blended urea ( 4.67 tons $\mathrm{ha}^{-1}$ grains), about $28 \%$ increase in grain yield was observed as compared to the control. About $3.5 \%$ increase was observed with the application of recommended $\mathrm{Zn}$ as $\mathrm{ZnSO}_{4}$ (3.92 tons ha ${ }^{-1}$ grains) compared to the control treatment. The application of $1.5 \%$ bio-activated $\mathrm{Zn}$ coated urea caused an increase of 9.8 and $19.6 \%$ in grain yield as compared to $1.5 \% \mathrm{Zn}$ coated and $1.5 \%$ Zn blended urea, respectively.

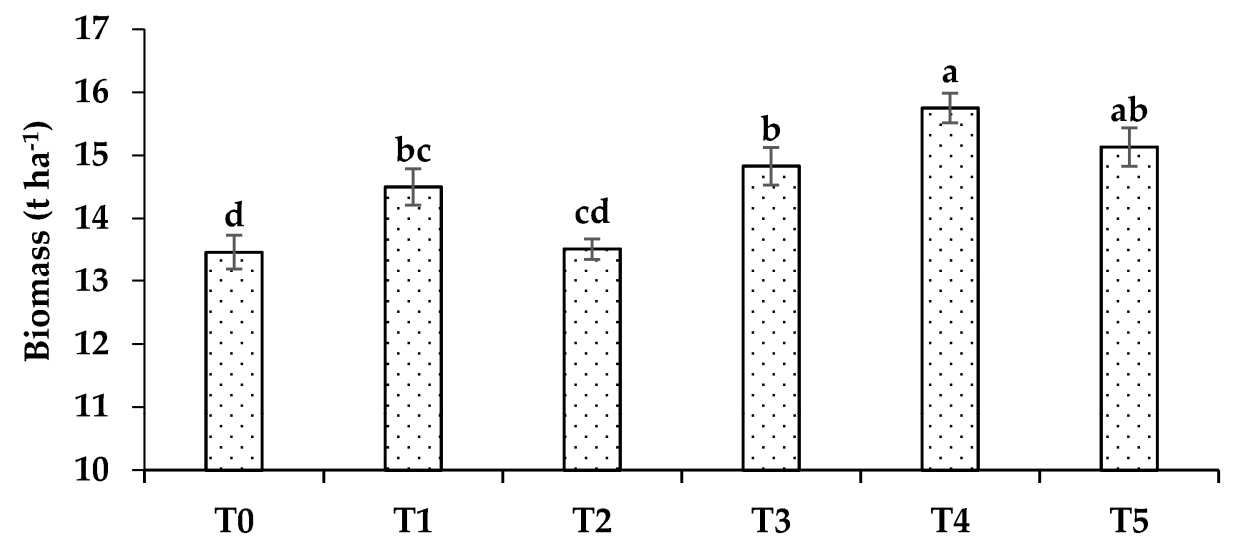

(a)

Figure 4. Cont. 


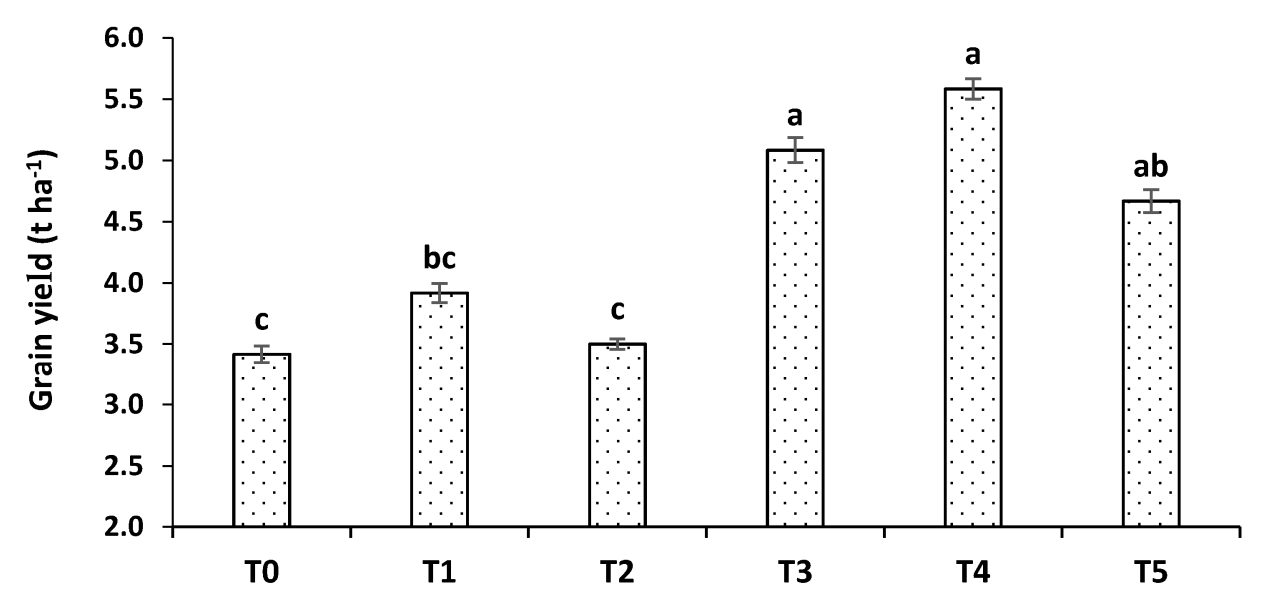

(b)

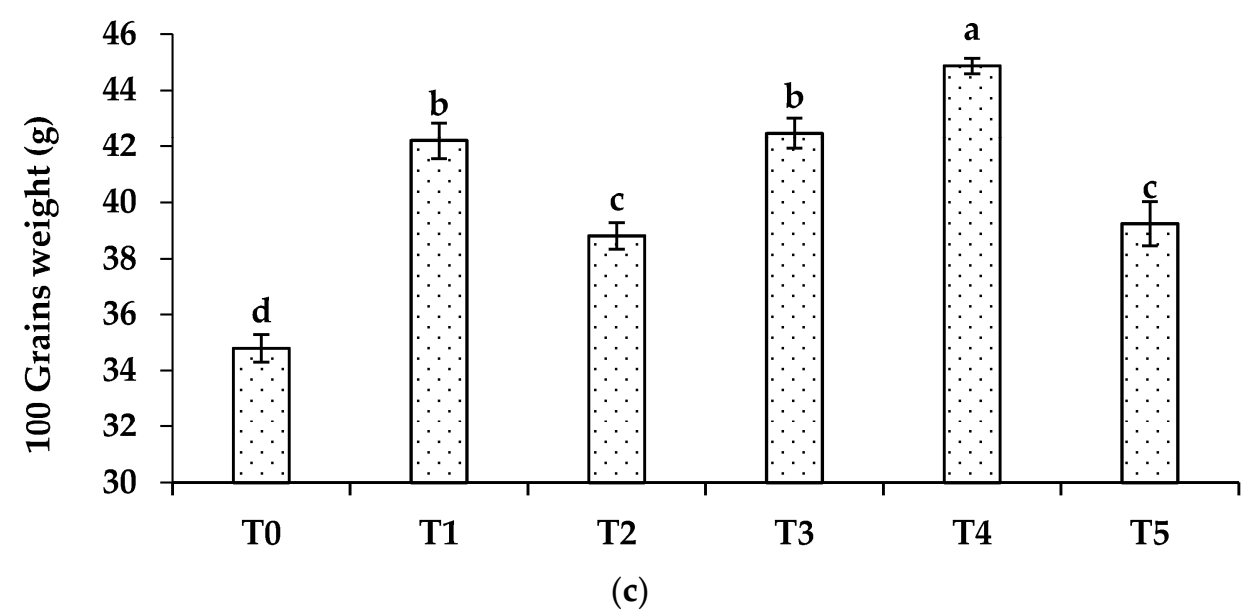

Figure 4. Comparative effectiveness of different $\mathrm{Zn}$ formulations of urea regarding yield parameters of wheat (a) Biomass (tons/ha), (b) Grain yield (tons $/$ ha), and (c) 100 grains weight. Where $\mathrm{T}_{0}=$ no $\mathrm{Zn} ; \mathrm{T}_{1}=\operatorname{recommended} \mathrm{Zn}\left(\mathrm{ZnSO}_{4}\right) ; \mathrm{T}_{2}=$ $\mathrm{ZSB} ; \mathrm{T}_{3}=1.5 \% \mathrm{Zn}$ coated urea $(\mathrm{ZnO}) ; \mathrm{T}_{4}=1.5 \%$ bio-activated $\mathrm{Zn}$ coated urea $(\mathrm{ZnO}) ;$ and $\mathrm{T}_{5}=1.5 \% \mathrm{Zn}$ blended urea $(\mathrm{ZnO})$. Means sharing the same letters do not differ significantly $(p<0.05)$.

Data presented in Figure 4c showed that different $\mathrm{Zn}$ formulations have a statistically significant effect $(p<0.05)$ on the 100-grain weight of wheat. With the application of recommended $\mathrm{Zn}$ as $\mathrm{ZnSO}_{4}(42.19 \mathrm{~g}), 19 \%$ increase in 100-grain weight was observed compared to the control ( $34.79 \mathrm{~g})$. Application of $1.5 \%$ bio-activated $\mathrm{Zn}$ coated urea resulted in the maximum ( $44.87 \mathrm{~g}$ ) 100-grain weight compared to all other treatments. The treatments with $1.5 \% \mathrm{Zn}$ coated $(42.47 \mathrm{~g})$ and $1.5 \% \mathrm{Zn}$ blended urea $(39.25 \mathrm{~g})$ showed 18.6 and $11 \%$ increase in 100-grain weight as compared to the control (no Zn). The application of 1.5\% bio-activated Zn coated urea showed 6 and $12.5 \%$ increase as compared to $1.5 \%$ $\mathrm{Zn}$ coated and $1.5 \% \mathrm{Zn}$ blended urea, respectively. The alone use of ZSB (38.81 g) caused $11 \%$ increase in 100-grain weight with respect to the control. The application of $1.5 \%$ bio-activated Zn coated urea caused an increase of 5.6 and 14.3\% in 100-grain weight as compared to $1.5 \% \mathrm{Zn}$ coated and $1.5 \% \mathrm{Zn}$ blended urea, respectively.

\subsection{Quality Parameters}

Data regarding the impact of different $\mathrm{Zn}$ formulations after the bio-activation and coating of $\mathrm{ZnO}$ on different quality parameters of wheat is presented in Table 1. Regarding ash (minerals) contents (\%), the coating and bio-activation of $\mathrm{Zn}$ at the level of $1.5 \%$ resulted in the maximum increase compared to the control with no $\mathrm{Zn}$ application. The application of $1.5 \%$ bio-activated $\mathrm{Zn}$ coated urea and recommended $\mathrm{Zn}\left(\mathrm{ZnSO}_{4}\right)$ showed almost similar results regarding ash contents i.e., 6.06 and $5.70 \%$, respectively. The treatments where 
$1.5 \% \mathrm{Zn}$ coated and $1.5 \% \mathrm{Zn}$ blended urea were applied showed 5.0 and $4.1 \%$ ash contents. ZSB (Bacillus sp.) and the control showed 4 and 3\% ash contents. In all these treatments, $1.5 \%$ bio-activated $\mathrm{Zn}$ coated urea showed $52 \%$ increase over the control while 19 and $30 \%$ increase as compared to $1.5 \% \mathrm{Zn}$ coated and $1.5 \% \mathrm{Zn}$ blended urea, respectively. The application of $1.5 \%$ bio-activated $\mathrm{Zn}$ coated urea caused an increase of 23.7 and $43.8 \%$ in ash contents as compared to $1.5 \% \mathrm{Zn}$ coated and $1.5 \% \mathrm{Zn}$ blended urea, respectively.

Table 1. Comparative effectiveness of the optimum level of zinc blended, zinc coated, and bioactivated zinc-coated urea to improve quality parameters under field conditions in wheat.

\begin{tabular}{lccccc}
\hline Treatment & Ash Contents (\%) & Oil Contents (\%) & N (\%) & Protein (\%) & Zn ( $\left.\boldsymbol{~ ( \% ~ g ~}^{-1} \mathbf{D W}\right)$ \\
\hline $\mathrm{No} \mathrm{Zn}_{\mathrm{ZnSO}}$ & $2.9 \pm 0.09 \mathrm{c}$ & $0.04 \pm 0.004 \mathrm{~b}$ & $1.80 \pm 0.02 \mathrm{c}$ & $10.5 \pm 0.23 \mathrm{~d}$ & $34.5 \pm 0.2 \mathrm{f}$ \\
$\mathrm{ZSB}$ & $5.7 \pm 0.09 \mathrm{ab}$ & $0.07 \pm 0.004 \mathrm{ab}$ & $2.50 \pm 0.09 \mathrm{a}$ & $14.3 \pm 0.2 \mathrm{~b}$ & $43.5 \pm 0.3 \mathrm{~b}$ \\
$1.5 \%$ Zn coated urea & $4.0 \pm 0.09 \mathrm{bc}$ & $0.07 \pm 0.002 \mathrm{ab}$ & $2.20 \pm 0.04 \mathrm{~b}$ & $12.5 \pm 0.3 \mathrm{c}$ & $37.5 \pm 0.2 \mathrm{e}$ \\
$1.5 \%$ bio-activated Zn coated urea & $5.0 \pm 0.3 \mathrm{ab}$ & $0.07 \pm 0.002 \mathrm{ab}$ & $2.40 \pm 0.04 \mathrm{a}$ & $13.9 \pm 0.3 \mathrm{~b}$ & $38.2 \pm 0.09 \mathrm{~d}$ \\
$1.5 \%$ Zn blended urea & $6.0 \pm 0.4 \mathrm{a}$ & $0.09 \pm 0.002 \mathrm{a}$ & $2.60 \pm 0.14 \mathrm{a}$ & $14.9 \pm 0.2 \mathrm{a}$ & $45.2 \pm 0.09 \mathrm{a}$ \\
LSD & $4.1 \pm 0.04 \mathrm{bc}$ & $0.05 \pm 0.002 \mathrm{~b}$ & $2.43 \pm 0.03 \mathrm{ab}$ & $13.8 \pm 0.2 \mathrm{~b}$ & $42.2 \pm 0.094 \mathrm{c}$ \\
\hline
\end{tabular}

Note: Values show means \pm S.E. where $n=3$. Means sharing the same letters within the column do not differ significantly $(p<0.05)$.

In the case of oil contents, all treatments showed significant effects however, the maximum increase (55\%) was observed with the application of $1.5 \%$ bio-activated $\mathrm{Zn}$ coated urea as compared to the control where no Zn was applied. Similarly, the application of $1.5 \% \mathrm{Zn}$ coated and $1.5 \% \mathrm{Zn}$ blended urea showed an increase of 39 and $21 \%$ in oil contents, respectively as compared to the control. In comparison to recommended $\mathrm{Zn}$ $\left(\mathrm{ZnSO}_{4}\right)$, an increase of $33 \%$ was recorded with the application of $1.5 \%$ bio-activated $\mathrm{Zn}$ coated urea. The application of $1.5 \%$ bio-activated $\mathrm{Zn}$ coated urea caused an increase of 23.4 and $66.7 \%$ in oil contents as compared to $1.5 \% \mathrm{Zn}$ coated and $1.5 \% \mathrm{Zn}$ blended urea, respectively.

A statistically significant effect of different $\mathrm{Zn}$ formulations was observed in the case of nitrogen $(\mathrm{N})$ contents in wheat grains (Table 1). It was clear from the data that the application of $1.5 \%$ bio-activated $\mathrm{Zn}$ coated urea showed $2.60 \% \mathrm{~N}$ contents, which were $29.65 \%$ more as compared to the control (no Zn). With the application of $1.5 \% \mathrm{Zn}$ coated and $1.5 \% \mathrm{Zn}$ blended urea, an increase of 24.18 and $23.86 \%$, respectively in $\mathrm{N}$ contents was recorded compared to the control. The recommended $\mathrm{Zn}\left(\mathrm{ZnSO}_{4}\right)$ showed $2.50 \% \mathrm{~N}$ contents that were $1.8 \%$ more as compared to the control. As compared to recommended $\mathrm{Zn}\left(\mathrm{ZnSO}_{4}\right), 1.5 \%$ bio-activated $\mathrm{Zn}$ coated urea showed an increase of $5 \%$ in $\mathrm{N}$ contents. The application of $1.5 \%$ bio-activated $\mathrm{Zn}$ coated urea caused an increase of 7.8 and $8.2 \%$ in $\mathrm{N}$ contents as compared to $1.5 \% \mathrm{Zn}$ coated and $1.5 \% \mathrm{Zn}$ blended urea, respectively.

The application of different $\mathrm{Zn}$ formulations was also tested for protein contents of wheat (Table 1). The data indicated that all treatments showed statistically significant effects $(p<0.05)$ as compared to the control. The use of $1.5 \%$ bio-activated $\mathrm{Zn}(\mathrm{ZnO})$ coated urea was more effective and it caused an increase of $30 \%$ in protein contents compared to the control. It was followed by recommended $\mathrm{Zn}\left(\mathrm{ZnSO}_{4}\right)$ with $14.3 \%, 1.5 \% \mathrm{Zn}$ coated with $13.9 \%, 1.5 \%$ Zn blended urea with $13.8 \%$, ZSB (Bacillus sp.) with $12.5 \%$ and the control with $10.5 \%$ protein contents. The application of $1.5 \%$ bio-activated $\mathrm{Zn}$ coated urea caused an increase of 6.4 and $7.8 \%$ in protein contents as compared to $1.5 \% \mathrm{Zn}$ coated and $1.5 \% \mathrm{Zn}$ blended urea, respectively.

The effect of different $\mathrm{Zn}$ formulations on the grain $\mathrm{Zn}$ concentration of wheat grains is shown in Table 1. The data clearly showed that the application of $\mathrm{Zn}$ in different forms significantly $(p<0.05)$ increased the grain $\mathrm{Zn}$ concentration. The use of $1.5 \%$ bio-activated $\mathrm{Zn}$ coated urea showed $23.60 \%$ increase in grain $\mathrm{Zn}$ concentration as compared to the control. While the treatments with $1.5 \% \mathrm{Zn}$ coated urea and $1.5 \% \mathrm{Zn}$ blended urea resulted in 9.60 and $17.85 \%$ increase in grain $\mathrm{Zn}$ concentration as compared to the control. The recommended $\mathrm{Zn}$ application $\left(\mathrm{ZnSO}_{4}\right)$ increased grain $\mathrm{Zn}$ concentration up to $20.6 \%$ as 
compared to the control. The bacterium ZSB i.e., Bacillus sp. AZ6 increased Zn contents up to $8 \%$ with respect to the control. As compared to recommended $\mathrm{Zn}\left(\mathrm{ZnSO}_{4}\right), 3.6 \%$ increase in grain $\mathrm{Zn}$ concentration was observed with $1.5 \%$ bio-activated $\mathrm{Zn}$ coated urea. The application of $1.5 \%$ bio-activated Zn coated urea caused an increase of 18.3 and $7.1 \%$ in grain $\mathrm{Zn}$ concentration as compared to $1.5 \% \mathrm{Zn}$ coated and $1.5 \% \mathrm{Zn}$ blended urea, respectively.

\section{Discussion}

Zinc, being a micronutrient, is involved in a wide variety of physiological processes [2]. It is required for optimum growth, yield, and quality of crop produce. Different approaches have been adopted to supply $\mathrm{Zn}$ to the plants such as soil, foliar, and soil + foliar application of chemical fertilizers, organic fertilizers, etc. The main issues with chemical fertilizers are their detrimental effects on soil ecology and lower solubility in soil, which make these approaches not feasible for poor farmers. On other hand, the use of PGPR (plant growthpromoting rhizobacteria) is an economical and environment friendly approach. The use of bio-inoculants such as bacteria could be a viable option to enhance $\mathrm{Zn}$ bioavailability and to achieve the objective of low input and sustainable agriculture to overcome Zn deficiency in soils and plants [42].

In soils, about $90 \%$ of $\mathrm{Zn}$ is present in an insoluble form, which is not available for plant uptake. On the other hand, metal salts solubilization is an important feature of so-called PGPR. Normally, PGPR mobilizes the nutrients by the secretion of organic acids, chelating agents (siderophores), and through exchange reactions [43]. Various reports have confirmed that PGPR secretes siderophores, gluconate, or the derivatives of gluconic acids, e.g., 2 and 5 ketogluconic acid, and various other organic acids for the mobilization of $\mathrm{Zn}$ and iron in soil [44-47]. Use of Zn solubilizing PGPR to enhance the growth and yield of crop plants is expected to become an emerging trend in contemporary agriculture in the near future. In the same way, bio-activation of an insoluble source of $\mathrm{Zn}$ i.e., $\mathrm{ZnO}$ to enhance $\mathrm{Zn}$ bioavailability and then the coating of this bio-activated $\mathrm{Zn}(\mathrm{ZnO})$ on urea could be an effective and sustainable approach to enhance $\mathrm{Zn}$ bioavailability in soil and biofortification of $\mathrm{Zn}$ in wheat grains, thereby improving physiology and quality of crops. Prasad and his coworkers reported in 2013 that the major benefit of $Z n$ coated urea is saving the amount of $\mathrm{Zn}$ to be applied, only $2.83 \mathrm{~kg} \mathrm{Zn} \mathrm{ha}^{-1}$ was required with $\mathrm{Zn}$ coated urea as against $6 \mathrm{~kg} \mathrm{Zn} \mathrm{ha}^{-1}$ in the case of soil + foliar application of $\mathrm{ZnSO}_{4}$. The $\mathrm{Zn}$ coated urea is therefore a favorable fertilizer in developing countries with small landholding farmers [48].

$\mathrm{ZnO}$ is sparingly soluble and not readily available to crop plants but through bioactivation and coating of $\mathrm{ZnO}$ at the level of 1.5\%, the maximum response was recorded regarding growth, yield, and physiological parameters of wheat under both field conditions in the present study. This problem could be overcome via bio-activated $\mathrm{Zn}$ coated urea as it controls the formation of insoluble $\mathrm{Zn}$ compounds due to the presence of organic acids. In the previous studies, the effective results were achieved by the application of $2 \% \mathrm{ZnO}$ coated urea in the wheat-rice cropping system in the present investigation, the maximum increase in most of the growth, physiological, yield, and quality parameters of wheat recorded was observed with the application of $1.5 \%$ bio-activated $(\mathrm{Zn}) \mathrm{ZnO}$ coated urea.

The physiological parameters such as carbonic anhydrase (CA) activity in which $\mathrm{Zn}$ act as a cofactor improved significantly with the application of $\mathrm{Zn}$ in $\mathrm{Zn}$ deficient soils, especially in rice-wheat cultivated areas [49]. Carbonic anhydrase activity decreases in many plants under $\mathrm{Zn}$ deficit conditions [50]. CA activity is directly related to the $\mathrm{Zn}$ concentration in plants. Under severe $\mathrm{Zn}$ deficient conditions, no activity of CA was observed [51]. For more activity of CA in the mesophyll cells, $\mathrm{Zn}$ application is necessary. The activity of $\mathrm{CA}$ is an indicator for the levels of physiologically active $\mathrm{Zn}$ [50]. Due to the involvement of $\mathrm{CA}$ in $\mathrm{CO}_{2}$ fixation during photosynthesis, $\mathrm{Zn}$ application significantly improved photosynthesis, which automatically increased all other growth, physiological, and yield parameters [52]. The ZSB used in the present study could produce auxin, which might have increased the root growth of plants and ultimately increased the nutrients 
uptake [53]. Zinc has a great role in membrane permeability; electrolyte leakage is the direct measurement of membrane permeability. With the application of $\mathrm{Zn}$, the decreased value of electrolyte leakage was observed but the maximum reduction in electrolyte leakage was observed in the plots, which received 1.5\% bio-activated Zn coated urea.

The cereals (wheat, rice, maize, etc.) are important food crops in developing countries, cultivated on large areas. Cereals being a staple food for the majority of people, the quality parameters like proteins, nitrogen, oil, ash contents in grains in wheat need to be assessed. In the present study, these parameters were significantly improved with the application of $\mathrm{Zn}$ and the maximum increase was observed with $1.5 \%$ bio-activated $\mathrm{Zn}$ coated urea. These results conform with the findings of $[54,55]$. The increase in quality parameters might be due to the contribution of $\mathrm{Zn}$ during photosynthesis, starch, and carbohydrate metabolism. Zn also starts glutamic dehydrogenase activity, RNA and DNA synthesis, which enhance gluten accumulation during the later stages of grain filling [55,56]. As $\mathrm{N}$ and $\mathrm{Zn}$ have a synergistic effect so the proper application of $\mathrm{Zn}$ improved $\mathrm{N}$ concentration in grains was obtained [57]. In the present study, dry matter (\%) increased while moisture (\%) decreased with $\mathrm{Zn}$ fertilization and these results are in agreement with the [58]. It has also been reported that oil contents are increased with the application of proper $\mathrm{Zn}$ [59].

The yield parameters such as grains yields and biomass production increased significantly with the application of $\mathrm{Zn}$ and the maximum increase was recorded with the application of $1.5 \%$ bio-activated Zn coated urea. Our results are in line with Zeb et al. [20] who reported improved yield parameters with the application of Zn. Grain production is an important parameter contributing towards yield, with the application of $\mathrm{Zn}$, a significant increase in grain yield of wheat was observed in the present study.

\section{Conclusions}

Bio-activation and coating of $\mathrm{Zn}$ on urea to supply $\mathrm{Zn}$ to plants is a novel, economical, and eco-friendly approach. It also saves farmers time as compared to the application of $\mathrm{Zn}$ and urea separately. The application of $1.5 \%$ bio-activated $\mathrm{Zn}$ coated urea has a marked effect not only on plant growth, yield, and physiological parameters but also on $\mathrm{Zn}$ biofortification of wheat under field conditions. Moreover, cereals, especially wheat grown on $\mathrm{Zn}$ deficient soil, 1.5\% bio-activated $\mathrm{Zn}(\mathrm{ZnO})$ coated urea is found effective in improving the $\mathrm{Zn}$ contents and quality parameters of wheat grains. Therefore, the application of bio-activated $\mathrm{Zn}(\mathrm{ZnO})$ coated urea could be a sustainable approach for $\mathrm{Zn}$ biofortification of wheat under farmers' field conditions. However, to warrant its practical application, rigorous studies under variable field conditions are required to authenticate its efficacy in the future.

Author Contributions: Conceptualization, Q.N. and A.H.; methodology, A.D.; software, A.M.; validation, A.M., A.A. and I.S.; formal analysis, X.W., N.P.; investigation, T.A. resources, T.A.; data curation, Q.N., A.A.; writing — original draft preparation, Q.N.; writing-review and editing, A.M.; supervision, A.H., T.A., M.N. All authors have read and agreed to the published version of the manuscript.

Funding: This research received no external funding.

Institutional Review Board Statement: Not Applicable.

Informed Consent Statement: Not Applicable.

Data Availability Statement: Prepared from the Dr. Qudsia Nazir (first author) PhD thesis. And PhD thsis is availabale online on HEC website. http:/ / prr.hec.gov.pk/jspui/handle/123456789/9838.

Acknowledgments: The authors acknowledge the Institute of Soil \& Environmental Sciences, University of Agriculture, Faisalabad-Pakistan for the provision of required research facilities.

Conflicts of Interest: The authors declare no conflict of interest. 


\section{References}

1. Alloway, B.J. Zinc in Soils and Crop Nutrition. Publication of International Zinc. 2004. Available online: http://www.iza.com/ Documents/Communications/Publications/ALLOWAY_PRINT.pdf (accessed on 5 February 2021).

2. Broadley, M.R.; White, P.J.; Hammond, J.P.; Zelko, I.; Lux, A. Zinc in plants. New Phytol. 2007, 173, 677-702.

3. Brennan, R.F. Zinc Application and Its Availability to Plants. Ph.D. Thesis, Murdoch University, Murdoch, Australia, 2005.

4. Disante, K.B.; Fuentes, D.; Cortina, J. Response to drought of Zn-stressed Quercus suber L. seedlings. Environ. Exp. Bot. 2010, 70, 96-103. [CrossRef]

5. Peck, A.W.; McDonald, G.K. Adequate zinc nutrition alleviates the adverse effects of heat stress in bread wheat. Plant Soil 2010, 37, 355-374.

6. Tavallali, V.; Rahemi, M.; Eshghi, S.; Kholdebarin, B.; Ramezanian, A. Zinc alleviates salt stress and increases antioxidant enzyme activity in the leaves of pistachio (Pistacia vera L.'Badami') seedlings. Turk. J. Agric. For. 2010, 34, 349-359.

7. Cakmak, I. Tansley Review No. 111: Possible roles of zinc in protecting plant cells from damage by reactive oxygen species. New Phytol. 2000, 146, 185-205. [CrossRef] [PubMed]

8. Shah, H.; Siderius, C.; Hellegers, P. Cost and effectiveness of in-season strategies for coping with weather variability in Pakistan's agriculture. Agric. Syst. 2020, 178, 102746. [CrossRef]

9. Pakistan Economic Survey. Highlights of Pakistan Economic Survey Report, Section Agriculture, Ministry of Econmics Affairs Pakistan, Pakistan, 2018-2019; Government of Pakistan Finance Division: Islamabad, Pakistan, 2019; pp. 12-33.

10. FAO. Food Supply Database (2007); Food and Agriculture Organization: Rome, Italy, 2012. Available online: http:/ /faostat.fao.org/ site/609/default.aspx\#ancor (accessed on 1 June 2012).

11. Kiekens, L. Zinc in heavy metals. In Soils; Alloway, B.J., Ed.; Blackie Academic and Professional: London, UK, 1995.

12. Cakmak, I. Enrichment of cereals grains with zinc: Agronomic or genetic biofortification? Plant Soil 2008, 302, 1-17. [CrossRef]

13. Joy, E.J.M.; Ahmad, W.; Zia, M.H.; Kumssa, D.B.; Young, S.D.; Ander, E.L.; Watts, M.J.; Stein, A.J.; Broadley, M.R. Valuing increased zinc (Zn) fertilizer-use in Pakistan. Plant Soil 2017, 411, 139-150. [CrossRef]

14. Aziz, M.Z.; Yaseen, M.; Abbas, T.; Naveed, M.; Mustafa, A.; Hamid, Y.; Saeed, Q.; Xu, M.G. Foliar application of micronutrients enhance crop stand, yield, and the biofortification essential for human health of different wheat cultivars. J. Integr. Agric. 2018, 18, 1369-1376. [CrossRef]

15. Khalifa, R.K.H.M.; Shaaban, S.H.A.; Rawia, A. Effect of foliar application of zinc sulfate and boric acid on growth, yield, and chemical constituents of iris plants. OJAS 2011, 4, 130-144.

16. Ashraf, M.N.; Aziz, T.; Maqsood, M.A.; Bilal, H.M.; Raza, S.; Zia, M.; Mustafa, A.; Xu, M.; Wang, Y. Evaluating organic materials coating on urea as potential nitrification inhibitors for enhanced nitrogen recovery and growth of maize (Zea mays). Int. J. Agric. Biol. 2019, 22, 1102-1108.

17. Aziz, M.Z.; Yaseen, M.; Naveed, M.; Wang, X.; Fatima, K.; Saeed, Q.; Mustafa, A. Polymer-Paraburkholderia phytofirmans PsJN Coated Diammonium Phosphate Enhanced Microbial Survival, Phosphorous Use Efficiency, and Production of Wheat. Agronomy 2020, 10, 1344. [CrossRef]

18. Wang, X.; Fan, J.; Xing, Y.; Xu, G.; Wang, H.; Deng, J.; Wang, Y.; Zhang, F.; Li, P.; Li, Z. The effects of mulch and nitrogen fertilizer on the soil environment of crop plants. Adv. Agron. 2019, 153, 121-173.

19. Wang, X.; Wang, G.; Guo, T.; Xing, Y.; Mo, F.; Wang, H.; Fan, J.; Zhang, F. Effects of plastic mulch and nitrogen fertilizer on the soil microbial community, enzymatic activity and yield performance in a dryland maize cropping system. Eur. J. Soil Sci. 2021, 72, 400-412. [CrossRef]

20. Zeb, H.; Hussain, A.; Naveed, M.; Ditta, A.; Ahmad, S.; Jamshaid, M.U.; Ahmad, H.T.; Hussain, M.B.; Aziz, R.; Haider, M.S. Compost enriched with $\mathrm{ZnO}$ and $\mathrm{Zn}$-solubilising bacteria improves yield and $\mathrm{Zn}$-fortification in flooded rice. Ital. J. Agron. 2018, 13, 1295.

21. Bhatt, K.; Maheshwari, D.K. Zinc solubilizing bacteria (Bacillus megaterium) with multifarious plant growth promoting activities alleviates growth in Capsicum annuum L. Biotech 2020, 10, 36. [CrossRef]

22. Hussain, A.; Zahir, Z.A.; Ditta, A.; Tahir, M.U.; Ahmad, M.; Mumtaz, M.Z.; Hayat, K.; Hussain, S. Production and implication of bio-activated organic fertilizer enriched with zinc-solubilizing bacteria to boost up maize (Zea mays L.) production and biofortification under two cropping seasons. Agronomy 2020, 10, 39. [CrossRef]

23. Naseer, I.; Ahmad, M.; Hussain, A.; Jamil, M. Potential of zinc solubilizing Bacillus strains to improve rice growth under axenic conditions. Pak. J. Agric. Sci. 2020, 57, 1057-1071.

24. Ullah, A.; Farooq, M.; Nadeem, F.; Rehman, A.; Hussain, M.; Nawaz, A.; Naveed, M. Zinc Application in Combination with Zinc Solubilizing Enterobacter sp. MN17 Improved Productivity, Profitability, Zinc Efficiency, and Quality of Desi Chickpea. Soil Sci. Plant Nutr. 2020. [CrossRef]

25. Ahmad, H.T.; Hussain, A.; Aimen, A.; Jamshaid, M.U.; Ditta, A.; Asghar, H.N.; Zahir, Z.A. Improving resilience against drought stress among crop plants through inoculation of plant growth-promoting rhizobacteria. In Resilient Environment and Plant Potential; Husen, A., Jawaid, M., Eds.; Springer Science + Business Media: New York, NY, USA, 2020; In Press.

26. Sabir, A.; Naveed, M.; Bashir, M.A.; Hussain, A.; Mustafa, A.; Zahir, Z.A.; Kamran, M.; Ditta, A.; Núñez-Delgado, A.; Saeed, Q.; et al. Cadmium mediated phytotoxic impacts in Brassica napus: Managing growth, physiological and oxidative disturbances through combined use of biochar and Enterobacter sp. MN17. J. Environ. Manag. 2020, 265, 110522. [CrossRef] 
27. Ullah, N.; Ditta, A.; Khalid, A.; Mehmood, S.; Rizwan, M.S.; Mubeen, F.; Imtiaz, M. Integrated effect of algal biochar and plant growth promoting rhizobacteria on physiology and growth of maize under deficit irrigations. Soil Sci. Plant Nutr. 2020, 20, 346-356. [CrossRef]

28. U.S. Salinity Lab. Staff. Diagnosis and Improvement of Saline and Alkali Soils; USDA Hand Book No. 60; U.S. Salinity Lab. Staff: Washington, DC, USA, 1954.

29. Moodie, C.D.; Smith, H.W.; Mccreery, R.A. Laboratory Manual for Soil Fertility; Department of Agronomy, State College of Washington Pullman: Washington, DC, USA, 1959; pp. 1-75.

30. Jackson, M.L. Soil Chemical Analysis; Prentice Hall, Inc.: Englewood Cliff, NJ, USA; New York, NY, USA, 1962.

31. Watanabe, F.S.; Olsen, S.R. Test of an ascorbic acid method for determining phosphorus in water and NaHCO3 extracts from soil. Soil Sci. Soc. Am. J. 1965, 29, 677-678. [CrossRef]

32. Soltanpour, P.N.; Workman, S. Modification of the $\mathrm{NH}_{4} \mathrm{HCO}_{3}$-DTPA soil test to omit carbon black. Commun. Soil Sci. Plant Anal. 1979, 10, 1411-1420. [CrossRef]

33. Hussain, A.; Arshad, M.; Zahir, Z.A.; Asghar, M. Prospects of zinc solubilizing bacteria for enhancing growth of maize. Pak. J. Agric. Sci. 2015, 52, 915-922.

34. Bunt, J.S.; Rovira, A.D. Microbiological studies of some subantarctic soils. J. Soil Sci. 1955, 6, 119-128. [CrossRef]

35. Nazir, Q.; Hussain, A.; Mumtaz, M.Z.; Niaz, A.; Arif, M.; Aftab, M.; Aslam, A.; Aziz, T. Efficiency of Various Formulations of Urea Coated with Bioaugmented (Bacillus sp.) ZnO to Improve Growth, Yield and Zn Contents of Wheat Grains. Pol. J. Environ. Stud. 2020, 30, 803-810. [CrossRef]

36. Lutts, S.; Kinet, J.M.; Bouharmont, J. Changes in plant response to $\mathrm{NaCl}$ during development of rice (Oryza sativa L.) varieties differing in salinity resistance. J. Exp. Bot. 1995, 46, 1843-1852. [CrossRef]

37. Dwivedi, R.S.; Randhawa, N.S. Evaluation of rapid test for hidden hunger of zinc in plants. Plant Soil 1974, 40, 45-451. [CrossRef]

38. AACC. Approved Methods of American Association of Cereal Chemists, 10th ed.; AACC: St. Paul, MN, USA, 2000.

39. Wolf, B. A comprehensive system of leaf analyses and its use for diagnosing crop nutrient status. Commun. Soil Sci. Plant Anal. 1982, 13, 1035-1059.

40. Shih, F.F.; Champagne, E.T.; Daigle, K.; Zarins, Z. Use of enzymes in the processing of protein products from rice bran and rice flour. Food Nahr. 1999, 43, 14-18.

41. Steel, R.G.D.; Torrie, J.H.; Dickey, D. Principle and Procedure of Statistical Analysis, 2nd ed.; McGraw Hill Book Co. Inc.: New York, NY, USA, 1997.

42. Mader, P.; Kiser, F.; Adholeya, A.; Singh, R.; Uppal, H.S.; Sharma, A.K.; Srivastava., R.; Sahai, V.; Aragno, M.; Wiemkein, A.; et al. Inoculation of root microorganisms for sustainable wheat-rice and wheat-black gram rotations in India. Soil Biol. Biochem. 2010, 43, 609-619. [CrossRef]

43. Chung, H.; Park, M.; Madhaiyan, M.; Seshadri, S.; Song, J.; Cho, H. Isolation and characterization of phosphate solubilizing bacteria from the rhizosphere of crop plants of Korea. Soil Biol. Biochem. 2005, 37, 1970-1974. [CrossRef]

44. Fasim, F.; Ahmed, N.; Parsons, R.; Gadd, G.M. Solubilization of zinc salts by bacterium isolated by the air environment of tannery. FEMS Microbiol. Lett. 2002, 213, 1-6. [CrossRef]

45. Saravanan, V.S.; Madhaiyan, M.; Thangaraju, M. Solubilization of Zinc Compounds by the diazotrophic, plant growth promoting bacterium Gluconacetobacter diazotrophicus. Chemosphere 2007, 66, 1794-1798. [CrossRef]

46. Tariq, M.; Hameed, S.; Malik, K.A.; Hafeez, F.Y. Plant root associated bacteria for zinc mobilization in rice. Pak. J. Bot. 2007, 39, 245.

47. Saravanan, V.S.; Kumar, M.R.; Sa, T.M. Microbial zinc solubilization and their role on plants. In Bacteria in Agrobiology: Plant Nutrient Management; Maheshwari, D.K., Ed.; Springer: Berlin, Germany, 2011; pp. 47-63.

48. Shivay, Y.S.; Prasad, R.; Singh, R.K.; Pal, M. Relative efficiency of zinc-coated urea and soil and foliar application of zinc sulphate on yield, nitrogen, phosphorus, potassium, zinc, and iron biofortification in grains and uptake by basmati rice (Oryza sativa L.). J. Agric. Sci. 2015, 7, 161. [CrossRef]

49. Reed, M.L.; Graham, D. Carbonic anhydrase in plants: Distribution, properties, and possible physiological functions. In Progress in Phytochemistry; Reinhold, L., Harborne, J.B., Swain, T., Eds.; Pergamon Press: Oxford, UK, 1980; Volume 7, pp. 47-94.

50. Gibson, T.S.; Leece, D.R. Estimation of physiologically active zinc in maize by biochemical assay. Plant Soil 1981, 146, 241-250. [CrossRef]

51. Guliev, N.M.; Bairamov, S.H.M.; Aliev, D.A. Functional organization of carbonic anhydrase in higher plants. Sov. Plant Physiol. 1992, 39, 537-544.

52. Escudero-Almanza, D.J.; Ojeda-Barrios, D.L.; Hernandez-Rodiriguez, O.A.; Chavez, E.S.; Ruiz-Anchondo, T.; Sida-Arreola, J. Carbonic anhydrase and zinc in plant physiology. Chil. J. Agric. Res. 2012, 72, 140-146. [CrossRef]

53. Kamilova, F.; Kravchenko, L.V.; Shaposhnikov, A.I.; Makarovaand, N.; Lugtenberg, B.J.J. Effects of the tomato pathogen Fusarium oxysporum sp. Radices-lycopersiciand of the biocontrol bacterium Pseudomonas fluorescens WCS365 on the composition of organic acids and sugars in tomato root exudate. Mol. Plant-Microbe Interac. 2006, 19, 1121-1126. [CrossRef]

54. Seadh, S.E.; El-Abady, M.I.; El-Ghamry, A.M.; Farouk, S. Influence of micronutrients foliar application and nitrogen fertilization on wheat yield and quality of grain and seed. J. Biol. Sci. 2009, 9, 851-858. [CrossRef]

55. Soleymani, A.; Shahrajabian, M.H. The effects of Fe, Mn, and Zn foliar application on yield, ash, and protein percentage of forage sorghum in climatic condition of Esfahan. Int. J. Biol. 2012, 4, 92. [CrossRef] 
56. Singh, O.; Kumar, S.; Awanish. Productivity and profitability of rice as influence by high fertility levels and their residual effect on wheat. Indian J. Agron. 2012, 57, 143-147.

57. Rehman, A.; Yasin, M.; Akram, M.; Awan, Z.I. Response of Zn applied and N sources in calcareous soils. Science 2002, 8, 100-104.

58. Sowokinos, J.R.; Preston, D.A. Maintenance of potato processing quality producers of selected nutrient contents of some tropical maize production. J. Cereal Sci. 1988, 16, 31-33.

59. Ikenie, J.; Amusa, N.; Obatolu, V. Nutrient composition and weight evaluation of some newly developed maize varieties in Nigeria. J. Food Technol. Afr. 2004, 7, 27-29. [CrossRef] 